\title{
SEJARAH LOKAL ADALAH SEJARAH MARITIM (NASIONAL) INDONESIA?
}

\author{
Imam Syafi'i \\ Pusat Penelitian Politik Lembaga Ilmu Pengetahuan Indonesia (P2P - LIPI)
}

\begin{abstract}
Abstrak: Penulisan sejarah atau historiografi di Indonesia terus mengalami perkembangan sejak masa kolonial. Berawal dari historiografi bercorak Nerlandosentis yang kemudian bergerak menjadi Indonesiasentris yang kemudian didominasi oleh penulisan sejarah bercorak militer di era Orde Baru. Pada era reformasi terdapat berbagai tuntutan perubahan arah historiografi di Indonesia termasuk upaya dekonstruksi sejarah dan penulisan sejarah lokal. Sejarah maritim juga mendapatkan perhatian khusus pada periode ini. Sejarah maritim di tingkat lokal telah menunjukkan kepada kita bahwa hampir semua wilayah di Indonesia memiliki konektivitas satu sama lain, menciptakan mobilitas, komunikasi, diaspora berbagai etnis yang membentuk peradaban bersama yang kosmopolit.
\end{abstract}

Kata-kata kunci: historiografi, sejarah lokal, sejarah nasional, sejarah maritim.

\begin{abstract}
Indonesian historiography has continued to develop since the colonial period. Starting from Nerlandocentric historiography which later shifted into Indonesiacentric which then dominated by the military narrative of history in the New Order era. In the reform era there were various demands for historiographical change in Indonesia including the efforts of historical deconstruction and local history writing. Maritime history also gained special attention in this period. Local maritime history has shown us that almost all regions of Indonesia have connectivity with each other, creating mobility, communication, diaspora of various ethnic groups that form a cosmopolitan cosmic civilization.
\end{abstract}

Keywords: historiography, local history, national history, maritime history.

Dalam historiografi kolonial, penulisan sejarah Indonesia (Hindia) sebenarnya telah dirintis sejak dekade awal abad ke-18. Pada era ini merupakan titik tolak penting dalam penulisan sejarah nasional yang kemudian dikenal dengan istilah "sejarah orang Belanda di Hindia/sejarah kolonial" (De Graaf, 1971, Van Leur, 1973). Istilah sejarah kolonial tentunya memiliki arti penulisan sejarah di era ini dirintis oleh orang-orang Belanda yang pernah datang ke Kepulauan Hindia atau sama sekali dari mereka yang belum pernah di dalam hidupnya singgah dan menetap di Kepulauan Hindia. Penulispenulis di era ini seringkali merupakan para pedagang Belanda, serdadu dan/atau administratur kolonial yang menuliskan kisah-kisah heroik kegiatan mereka dari berbagai dokumen arsip maupun kenangan-kenangan pribadi selama berada di Hindia. Semangatnya adalah memosisikan orang-orang Eropa dan Kristen-yang berawal dari kedatangan VOC, di atas orangorang yang dianggap sebagai pribumi yang animistis (De Graaf, 1971:9-10).

Nama-nama seperti Valentijn (16661727) "Oud en Nieuw Oost Indien"; Pieter van Dam (?) "Beschrijvinge der O.I Compagnie"; dapat dianggap sebagai generasi pertama yang merintis penulisan sejarah Hindia dengan penuh semangat yang di dalam setiap tulisannya mengagung-agungkan bangsanya sendiri dan secara bersamaan meremehkan kisah-kisah, warisan, dan aktivitas orang-orang pribumi yang dianggapnya sebagai bangsa asing dengan bahasa 
dan kebudayaan yang asing (De Graaf, 1971:9-10).

Berbeda dengan nama-nama tersebut di atas, Raffles (1781-1826), "History of Java" dan P.J Veth (1814-1896), "Java, Geografisch, Etnologisch, Historisch" telah memberikan porsi yang lebih besar terhadap sumber-sumber selain sumber kolonial. Raffles dibantu temannya yang seorang panembahan dari Sumenep, kemudian menulis sejarah Hindia (Jawa) sejak sebelum tahun abad ke-16 melalui sumber-sumber pribumi seperti artefak dan lainnya. Veth yang tidak pernah berkunjung ke wilayah Hindia mengumpulkan berbagai informasi dari dokumen-dokumen yang mungkin dapat dia akses dan menulis secara kritis "sejarah kolonial" dari perspektif orang-orang pribumi. Kemudian kita dapat membaca tulisan J Hageman (1817-1872) seorang juru tulis dan J.K.K de Jonge (18281879) yang bekerja di arsip kerajaan yang kemudian menulis sejarah Hindia lebih dari sekedar usaha yang dilakukan oleh para pendahulunya. Aksesnya yang tidak terbatas terhadap arsip kerajaan kemudian membuatnya leluasa menulis sejarah Hindia tidak hanya aktvitas orang-orang Eropa juga orang-orang pribumisekalipun masih terkait dengan keberadaan orang-orang Eropa (Abdullah dan Surjomihardjo, 1985:14-15).

Selama abad ke-19 hingga memasuki awal abad ke- 20, para penulis (sejarawan?) kolonial ini selalu terjebak di dalam romantisme pendahulu-pendahulu mereka. Peran besar orang-orang Eropa di dalam perkembangan di Hindia selalu ditonjolkan terutama terkait tindak tanduk para Gubernur Hindia, lebih-lebih upaya mereka memperluas wilayah kekuasaan melalui jalan perang.

Dalam konteks ini, penulis dari kalangan militer lebih mendominasi penulisan-penulisan tentang Hindia. Hal yang tidak banyak berubah, peran dan sumber- sumber dari orang-orang pribumi terus dikesampingkan. Sementara itu, menurut Sartono tradisi historiografi tradisional sesungguhnya masih terus berlangsung meskipun upaya kolonialisasi semakin kuat setidaknya hingga akhir abad ke-19 (Kartodirjo, 1995: 4-5). Situasi ini sesungguhnya tidak begitu aneh mengingat perkembangan penulisan sejarah di Eropa sejak abad ke-19 memosisikan sumbersumber pribumi yang kebetulan lebih banyak didominasi oleh sejarah/tradisi lisan diangg ap ahistoris. Tentunya kita pernah mendengar apa yang dikatakan salah satu penulis Eropa yakni Charles-Victor Langois dan Charles Seignobos yang mengatakan bahwa sejarawan tidak dapat bekerja tanpa dokumen, tidak ada dokumen tidak ada sejarah (Adam, 2000:xiii).

Pada saat yang bersamaan, sesungguhnya telah muncul penulispenulis yang mulai menempatkan peranperan orang lokal di dalam sejarah Hindia. Akhir abad ke- 19 dan awal abad ke- 20 memang menjadi penanda semakin banyaknya generasi dari penulis Eropa yang muncul untuk menuliskan tentang sejarah Hindia tanpa mengabaikan peran atau sumber dari orang-orang Hindia. Mengikuti jejak yang ditinggalkan oleh Raffles, namanama seperti Kern, Brandes, Pigeaud, Krom melakukan penelitian-penelitian sejarah Hindia sebelum 1600an. Kelompok lain dapat dimunculkan dan digolongkan sebagai orientalis adalah Kroeskamp yang menulis tentang Sejarah Minangkabau dan Snouck Hurgronje yang kemudian mengilhami kemenangan Kolonial dalam Perang Aceh (De Graaf, 1971:27). Satu nama yakni Hoessein Djajadiningrat, orang Hindia pertama yang tidak hanya menggunakan sumber sejarah lokal yakni Sejarah Banten, juga membandingkan dengan dokumen-dokumen kolonial dan melakukan iinterpretasi kritis dalam disertasinya yang memiliki judul asli, 
"Critische Beschouwing van de Sadjarah Banten".

Tidak hanya sekedar kritik terhadap penulisan ala "sejarah kolonial" yang terlalu memosisikan dokumen-dokumen kolonial pada posisi yang paling penting dan mengabaikan sumber-sumber lokal di Hindia. Muncul juga narasi-narasi baru yang lebih kritis terhadap eksistensi kolonial. Seorang bekas administratur kolonial kemudian menuliskan pengalamannya selama bekerja di tanah Hindia khususnya di Jawa (Banten) dalam bentuk novel berjudul, "Max Havelaar" (1859). Dia yang memiliki nama pena Multatuli mengkisahkan narasi baru tentang kolonialisme tidak lebih dari narasi tentang kekejaman, ketidakadilan, perampasan, kemiskinan, kelaparan yang dialami oleh orang-orang Lebak akibat sistem tanam paksa. Menurut Toer (1999), tulisan Multatuli yang dikenal dengan nama asli, Eduard Douwes Dekker, sebagai The Book that Colonialsm karena telah membuka mata dunia dan menginspirasi banyak tokoh untuk berjuang melakukan upaya dekolonisasi.

Dalam dekade ketiga abad ke-20, muncul nama J. C. Van Leur yang melakukan kritik terhadap penulisan sejarah Hindia di mana VOC dan penerusnya merupakan aktor tunggal yang mempengaruhi jalannya cerita di Hindia. Seorang sarjana Leiden yang kemudian bertugas sebagai administratur di Hindia Belanda dan meninggal sebagai seorang perwira Angkatan Laut Kerajaan Belanda pada masa Perang Pasifik (Leirissa, 1973:6).

Menurut J. C. Van Leur, penulisan sejarah Hindia tidak lebih dari deretan narasi yang dikategorikan berdasarkan jabatan Gubernur Jenderal di tanah jajahan. Hal ini dianggap meniru kategorisasi berdasarkan penulisan sejarah Eropa Barat dan Amerika Utara yang tidak terlepas dari sistem kerajaan yang konservatif, kekuasaan gereja, oligarki lama dan kemunculan kapitalisme awal. Bagi van Leur, yang kembali membuka dokumen-dokumen kolonial dengan interpretasi yang lebih kritis berhasil menarasikan kegiatan perdagangan orang-orang di Hindia tanpa terpengaruh keberadaan orang-orang Eropa (VOC), namun justru mereka terkadang mengikuti pola-pola tradisional yang sudah berkembang sejak lama. Ungkapan kritis van Leur (1973:11) dalam melihat tradisi historiografi kolonial sebagai berikut.

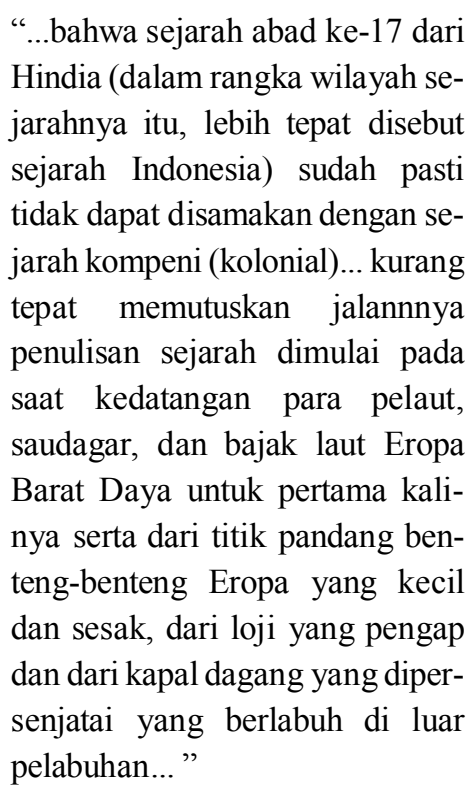
Hindia (dalam rangka wilayah sejarahnya itu, lebih tepat disebut sejarah Indonesia) sudah pasti tidak dapat disamakan dengan sejarah kompeni (kolonial)... kurang tepat memutuskan jalannnya penulisan sejarah dimulai pada saat kedatangan para pelaut, saudagar, dan bajak laut Eropa Barat Daya untuk pertama kalinya serta dari titik pandang benteng-benteng Eropa yang kecil dan sesak, dari loji yang pengap dan dari kapal dagang yang dipersenjatai yang berlabuh di luar pelabuhan..."

Dalam perkembangannya, kritik van Leur kemudian mendapatkan momentum ketika wilayah ini mendapatkan kemerdekaan sebagai sebuah nation- state. Sama halnya dengan negara-negara baru di wilayah Asia Tenggara lainnya-juga negara-negara baru di Asia dan Afrika pasca Perang Dunia II, upaya penulisan sejarah nasional Indonesia, menjadi kebutuhan yang cukup mendesak dan penting. Penulisan sejarah nasional diarahkan pada pembentukan identitas nasional dengan batasan-batasan politik-geografis warisan kolonial.

Faktanya wilayah ini merupakan
kesatuan dari wilayah-wilayah yang 
memiliki keberagaman etnis. Oleh karenanya, sejarah nasional Indonesia merupakan pengalaman kolektif dari masing-masing etnis, dengan persepsi, tujuan dan aspirasi yang berbeda sebagai sebuah negara-bangsa. Dalam seminar nasional pertama-yang kemudian dijadikan sebagai Hari Sejarah Indonesia, yang diadakan di Yogyakarta pada 14-18 Desember 1957, upaya membentuk identitas kolektif ini diakomodasi sebagai tujuan utama penulisan sejarah nasional. Bahwa upaya rekonstruksi sejarah nasional yang otentik harus selaras dengan visi nasional. Artinya, tidak hanya sekedar mengupayakan penulisan yang Indonesia-sentris, menggantikan penulisan Neerlando-sentris namun rekonstruksi ilmiah yang objektif dan kreatif tentang struktur kemasyarakatan dan dinamika kehidupan etnis tertentu sebagai unsur bangsa yang memiliki sejarahnya sendiri (unit historis yang independen), maupun hubungan di antara unsur-unsur bangsa yang lain. Juga, tidak sekedar mengambil peran penulis-penulis asing oleh penulis/ sejarawan nasional (lokal) (Abdullah, 2016:7) dan upaya mengembalikan sejarah pada yang tidak bersuara (masyarakat terjajah), masyarakat miskin (buruh, petani, nelayan, dst), perempuan dan anak (non elit) (Morrison, 2000:1516) di wilayah-wilayah periferi (lokal) melalui proses yang disebut sebagai humanisasi sejarah, bahwa sejarah bukan sekedar kuburan orang- orang besar (Kartodirjo, 1982:7).

\section{DEKOLONISASI SAMPAI DESEN- TRALISASI: PENYUSUNAN SE- JARAH NASIONAL INDONESIA YANG GAGAL?}

Pada dasarnya, melakukan kegiatan historiografi reflektif tidak hanya bersandar pada proses detradisionalisasi atau dekoloniasasi/nasionalisasi (termasuk upaya desentralisasi). Lebih dari itu, Sartono Kartodirdjo (1995) menyebut bawa historiografi merupakan upaya diplomatis di antara keduanya untuk mendapatkan gambaran masa lalu yang mendekati prinsipprinsip sejarah yang objektif. Historiografi tradisional seperti babad, hikayat, lontar, dan sejarah/tradisi lisan yang memang berkembang pada masyarakat kita di masa lalu, mewariskan tradisi penulisan sejarah dari dalam (history from within) dan historiografi kolonial memberikan pemahaman tentang studi sejarah kritis (Kartodirjo, 1995:6). Bahwa upaya ini tidak hanya sekedar pengujian terhadap metodologi sejarah modern, melainkan menguji dan merumuskan kembali klaim-klaim kebenaran dan/atau menyelidiki terbentuknya klaim kebenaran itu sendiri secara historis. Melalui pendekatan multidimensional approach, upaya ini menghindari prekonsepsi dan teori yang berat sebelah, dan menghindari kecenderungan sikap determinisme sebagai alat utama sejarawan (Kartodirjo, 1982:65-66). Dengan demikian, sejarah tidak hanya peristiwaperistiwa politik semata melainkan berbagai aktivitas sosial, ekonomi dan kultur dalam rentang waktu dan tempat tertentu namun memiliki keterkaitan satu sama lain (trans-lokal).

Dalam tradisi historiografi pasca kolonial, penulisan sejarah nasional (nationstate) tidak hanya dianggap sebagai kegiatan yang bersifat intelektual dan akademis semata juga sangat politis (Nordholt, 2008:1). Sejarah seakan-akan menjadi sinonim terhadap klaim kebenaran (truth claim) yang melegitimasi eksistensi individu atau kelompok tertentu, suatu bangsa tertentu tergantung dengan pemenang di dalam kontestasi kekuasaan (politik). Narasi-narasi (grand narrative) kemudian diciptakan berdasarkan kepentingan dan sentralitas elit penguasa sehingga batasan 
antara the real past dan just interpretation menjadi sangat kabur.

Baik di awal-awal kemerdekaan maupun awal kemunculan rezim Orde Baru, penulisan sejarah nasional sekedar upaya penyederhaan kompleksitas dari dinamika masyarakat dan masa lalunya. Negara menyusun klasifikasi sosial tunggal agar dapat mengendalikan warga masyarakatnya. Narasi-narasi alternatif yang memosisikan masyarakat sebagai sentralitas dalam sejarah tidak mendapatkan tempat karena metanarasi dalam sejarah nasional itu sendiri. Artinya, Historiografi Indonesiasentris tidak jauh berbeda dengan historiografi kolonial dengan versi yang berbeda namun tetap mengandung upaya pasifikasinya dan nasionalistik (chauvinisme) (Soedjatmoko, 1995:1). Dalam konteks ini, Bambang Purwanto (2006) menyebut bahwa upaya menulis sejarah nasional yang Indonesiasentris (pascakolonial) hanyalah usaha yang sia-sia.

Pada Orde Lama, penulisan sejarah secara politis disusun dalam semangat revolusi dan nasionalisme sebagai antitesa dari kolonialisme. Bahan ajar kemudian disusun dalam bentuk buku penulisan sejarah nasional yang menitikberatkan kepada sejarah pergerakan nasional yang penyusunanannya dipimpin oleh Ali Sastroamidjojo (Adam, 2010:78). Menurut rezim Orde Lama, penafsiran sejarah nasional harus bersumber pada prinsip-prinsip "Manipol Usdek". Era Orde Baru merupakan sebuah era di mana penulisan sejarah sepenuhnya dikontrol oleh kekuasaan. Sejarah telah ditalkukkan dan dikendalikan oleh arogansi dan sentralitas militer.

Penciptaan narasi tunggal oleh rezim Orde Baru tidak hanya menghilangkan peran masyarakat terutama di tingkat lokal, juga menghilangkan peran kelompok-kelompok lawan politik Orde Baru. Bagi Utrecht, kontrol dan penulisan sejarah yang dilakukan oleh Orde Baru dimulai sejak
1965 dan 1978. Periode ini penting dikarenakan menjadi awal kebangkitan rezim baru Soeharto (pasca 1965), dimulainya era pembangunan dan semakin kuatnya modal asing sejak tahun 1978 (Lane, 2011:8). Di era ini, pabrik penulisan sejarah nasional dikontrol ketat oleh militer sebagai salah satu dari tiga unsur utama di dalam rezim Orde Baru selain Golkar dan Soeharto sendiri. Historiografi Indonesia disusun untuk melegitimasi dan menciptaan mitos tentang peran militer yang telah menyelamatkan revolusi Indonesia dan narasi-narasi untuk melegitimasi peran mereka di dalam mengawal kedaulatan dan pembangunan nasional.

Sebenarnya narasi-narasi alternatif yang mengungkapkan tema-tema sejarah sosial terus diupayakan oleh Sartono Kartodirdjo di dalam penyusunan sejarah nasional di era Orde Baru. Namun demikian narasi tentang politik Orde Baru tetap mendominasi dan mulai merivisi apa yang telah disusun oleh Sartono. Narasi-narasi alternatif semakin menghilang setelah Sartono dan beberapa rekannya sebagai bagian dari tim Panitia Penyusunan Buku Standar Sejarah Nasional (PPBSN) (Adam, 2006: $x$-xi) satu persatu mundur dari proyek penulisan Sejarah Nasional Indonesia (SNI). Ketidaksepahaman/keberatan mereka terutama pada soal pengarusutamaan peran militer dan Soeharto sehingga mereka memilih untuk mundur. Sejak saat itu, sejarawan militer Nugroho Notosutanto menjadi pimpinan di dalam menciptakan sejarah yang hegemonik (Nordholt, 2008:11).

Penulisan sejarah nasional akhirnya merepresentasikan hegemoni kekuatan pusat. Sementara militer menjadi instrumen intervensi dengan dalih menghilangkan krisis yang mengancam persatuan dan pembangunan sentralistik. Kasus hubungan Jakarta dengan Papua dan Aceh menjadi penting untuk dilihat. 
Selama Orde Baru, narasi dari perspektif (lokal) tentang Aceh dan Papua dikerdilkan dengan dalih Indonesianisasi melalui pendekatan keamanan (militer) dan pembangunan. Dalam konteks ini kemudian, berbagai narasi dan ekspresi yang terbentuk dari identitas dan sejarah panjang Aceh dan Papua dianggap sebagai pembangkangan terhadap eksistensi Negara Kesatuan Republik Indonesia (NKRI).

Sejarah lokal kemudian diabaikan, pun jika harus ditulis dan diusahakan tetap berada dalam koridor yang ditetapkan negara. Pusat adalah penentu jalan cerita dan dinamika di tingkat lokal. Dalam konteks metodologi, pasifikasi sejarah lokal ini kemudian berdampak pada penekanan terhadap arsip-arsip negara sebagai sumber utama historiografi, sedangkan alternatifalternatif narasi/sumber di daerah diposisikan hanya sebagai dongeng, mitos, cerita rakyat atau sekedar ingatan kolektif yang tak berguna.

Setelah rezim militer Soeharto mulai runtuh, reformasi menjadi penanda usaha historiografi untuk orang-orang yang selama Orde Baru berkuasa telah dibungkam. Revisi-revisi sejarah dilakukan dimulai dengan pemeriksaan kembali buku-buku pelajaran di sekolah serta menulis ulang sejarah-sejarah lokal (identitas daerah dan identitas kesukuan). Buku-buku yang sebelumnya terlarang diterbitkan ulang dan disebarkan secara luas serta munculnya biografi-biografi tokoh yang meligitmasi kesalahan-kesalahan Orde Baru. Salah satu memoar kesaksian yang secara terang menuduh Soeharto dan militer terlibat dalam G30S adalah memoar Soebandrio, seorang Perdana Menteri masa Soekarno. Biografi kesaksiannya ini secara terang-terangan menyebutkan keterlibatan Soeharto dan militer yang didukung oleh Barat, AS. Penghujung buku ini ditutup dengan seruan untuk mengakhiri kebungkaman akibat rezim fasis Soeharto (Soebandrio, 2000: 9, 14, 68-69).

Narasi-narasi yang selama Orde Baru di kontrol sepenuhnya oleh kekuatan nasional di pusat, digantikan dengan narasi-narasi versi lokal atau yang dilokalkan. Proyek ini kemudian dikenal sebagai pelurusan sejarah nasional. Ironisnya, usaha desentralisasi dan bahkan demiliterisasi tidak sekedar merevisi peran Soeharto dan militer dalam sejarah Indonesia, tapi seakan-akan telah menguapkan sejarah Orde Baru yang telah hidup selama 30 tahun sebagai bagian dari historiografi Indonesia itu sendiri. Satu sisi usaha tersebut berupaya memberikan kesempatan terhadap semua orang dari pelbagai lapisan mendapatkan panggung sejarah. Sisi yang lain, arogansi baru muncul dan historiografi masih memilik kadar politik yang tinggi terutama jika menyangkut naik turunnya hubungan Jakarta dengan Aceh (Tiro, 1982, Hasan, 2016) dan Papua (Zed, 2012) atau sekitar peristiwa 1965 dan berbagai peristiwa turunannya (Lane, 2011).

\section{MEMOSISIKAN SEJARAH LOKAL DALAM KONTEKS SEJARAH NA- SIONAL}

Dalam konteks penulisan sejarah nasional pasca rezim otoritarian, sejarah lokal memang diposisikan secara konfrontatif dengan narasi yang dikembangkan oleh negara. Standar penulisan sejarah berdasarkan intervensi negara kemudian masuk ke dalam perdebatan tentang siapa tokoh yang paling mewakili dan berhak atas panggung sejarah, atau peristiwa-peristiwa (lokal) mana yang paling penting untuk dipilih menjadi bagian dari sejarah nasional? Sejarah sebagai peristiwa masa lalu lantas menjadi komoditas yang harus disesuaikan kebutuhan dan kepentingan bagi mereka 
yang menginginkan pengakuan-pengakuan atas eksistensi mereka.

Taufik Abdullah (1996), menyebutkan penulisan sejarah lokal tidak harus diikuti dengan janji-janji tentang sumbangan sejarah lokal itu sendiri kepada hal yang lebih besar, Sejarah Nasional Indonesia (SNI) misalnya. Memaksakan sejarah lokal berkaitan dengan SNI hanya akan menghasilkan sifat rendah diri dan anakronis dan sejarah lokal bukanlah sejarah nasional versi lokal. Tren penulisan sejarah lokal sebagai narasi nasional versi lokal terlihat dalam proyek penelitian dan pencatatan kebudayaan daerah. Proyek ini kemudian menghasilkan buku-buku tentang sejarah daerah (provinsi) yang ada di Indonesia, misal "Sejarah Daerah Jawa Timur", "Sejarah Kebangkitan Nasional Daerah Bali", "Peranan Rakyat Besuki (Jawa Timur) Pada Masa Perang Kemerdekaan", "Adat Istiadat Daerah Provinsi Daerah Istiwewa Aceh" dan lain sebagainya. Proyek penulisan sejarah lokal ini kemudian menggunakan periodisasi yang disepakati oleh negara dimulai dari jaman prasejarah, jaman kuna, jaman kedatangan VOC (jaman baru), jaman kebangkitan nasional, jaman pendudukan Jepang, jaman kemerdekaan, dan seterusnya.

Penulisan sejarah lokal dengan cara seperti ini sesungguhnya tidak memberikan sumbangan berarti terhadap pemahaman kita terhadap sejarah lokal itu sendiri. Bahwa hal-hal penting di dalam peristiwa nasional belum tentu mempengaruhi alur cerita yang terjadi di tingkat lokal di masa lalu. Juga sejarah nasional tidak serta merta merupakan peristiwa terpilih dan penting di tingkat lokal dan atau akumulasi dari berbagai peristiwa lokal. Sejarah lokal harus dipandang sebagai penglihatan kita terhadap masa lalu yang tidak hanya terbatas pada ruang lingkup geografis tertentu juga melihat eksistensi manusia lebih intim tanpa terjebak pada keterlibatan elit dan peristiwa besar sejarah. Oleh karenanya, sejarah lokal dapat berdiri secara otonom. Ia tidak sekedar dilihat sebagai sumbangsihnya di dalam penyusunan sejarah nasional, juga memberikan kita pemahaman tentang pengertian "diri" dan orang lain. Bahwa penulisan sejarah lokal yang membatasi diri dari lokalitas dan periode tertentu lebih menjanjikan terhadap kecermatan dan kedalaman di dalam memahami masyarakat tertentu sebagai bagian dari sejarah sosial dari masyarakat tertentu (Abdullah, 1996).

Tawaran sejarah sosial di dalam melihat peristiwa tertentu di waktu dan tempat tertentu yang diusulkan oleh Taufik Abdullah (1996) ini sebenarnya telah dirintis oleh gurunya, Sartono Kartodirdjo melalui tulisannya tentang Pemberontakan Petani Banten 1888. Upaya yang dilakukan oleh Sartono kemudian dikenal dengan mahzab Bulaksumur (Nursam, 2008) yang terus dilanjutkan oleh penerus Sartono seperti Taufik Abdullah (Sumatera Barat, 1927-33), Ibrahim T. Alfian (Aceh, 18731912), Djuliati Suroyo (Kedu, 1800-90), Kuntowijoyo (Madura, 1850-1940), A B Lapian (Laut Sulawesi, abad XIX), Suhartono (Surakarta, 1830-1920), dan lain-lain. Sebagian besar karya dari mahzab ini memfokuskan kajiannya kepada berbagai permasalahan sosial (sejarah sosial) dengan mengambil periode kolonial. Sejarah sosial akhrinya dimaknakan sebagai bagian dari proses humanisasi sejarah yang memberikan kesempatan lebih luas kepada masyarakat untuk mendapatkan panggung sejarahnya tanpa terjebak pada peristiwaperistiwa besar dan heroik.

Namun demikian, upaya ini penulisan sejarah lokal tidak serta merta terhindar dari situasi politik di saat penulisan itu dilakukan. Pasca Orde Baru, upaya penulisan sejarah lokal difokuskan kepada sejauh mana pengaruh rezim otoritarian mempengaruhi struktur sosial masyarakat 
di daerah dan sejauh mana proses desentralisasi setelahnya memunculkan berbagai fragmentasi premordial kedaerahan. Riwanto Tirtosudarmo (2007) dalam bukunya, "Mencari Indonesia: Demografi Politik Pasca Soeharto" memperlihatkan bahwa rekayasa demografi melalui transmigrasi yang dilakukan oleh negara bahkan sejak era kolonial (Maat, 2016), menekankan pada proses integrasi geografis untuk mendukung praktik ekonomi dan politik semata. Hal ini kemudian menciptakan segregasi sosial berdasarkan daerah asal, etnisitas, dan agama terutama di daerah-daerah tujuan program transmigrasi yang hampir selalu dimanfaatkan oleh kepentingan elit politik lokal (Tirtosudarmo, 2007).

Berdasarkan paradigma ini, upaya penulisan sejarah lokal yang dilakukan oleh Departemen Pendidikan Nasional (2001) sebagai bagian dari Proyek Peningkatan Kesadaran Sejarah Nasional masuk dalam sejauh mana segregasi ini mempengaruh dinamika sosial politik di tingkat lokal. Upaya ini kemudian menghasilkan dua buku yang terdiri dari dua tema besar yakni, 1) Konflik Komunal dan Ketersingkiran Sosial, dan 2) Pembangkangan Sipil dan Konflik Komunal. Selain itu, banyak Pemerintah Daerah (Pemda) berlombalomba menyusun sejarah lokal untuk mencari asal usul (kepentingan ulang tahun daerah), semakin tua usia suatu daerah, dianggap semakin membanggakan. Juga, sejarah lokal digunakan sebagai legitimasi untuk melengkapi usaha pemekaran wilayah dan atau pengusulan pahlawan daerah menjadi pahlawan nasional. Meskipun upaya-upaya ini tidak sepenuhnya dapat disalahkan, namun upaya penulisan sejarah lokal seperti ini tidak begitu banyak membantu kita lebih memahami kondisikondisi suatu wilayah tertentu.

Namun demikian, perkembangan penulisan sejarah lokal sangat menjanjikan agar mendapatkan keberagaman narasi, pengalaman sejarah dan interaksi antar/intra etnis di Indonesia sebagai sebuah $n a-$ tion-state. Banyak calon sarjana sejarah di Perguruan Tinggi (PT) di Indonesia menyusun tugas akhirnya bertitik tolak dari daerah asalnya. Hal ini tentunya menjadi peluang bagi mereka untuk dapat memberikan gambaran yang lebih holistic mengenai sejarah dari wilayah yang mereka teliti dengan berbagai topik yang lebih beragam. Mereka tentunya memiliki kesempatan dari segi waktu, akses, dan pemahaman terhadap kebiasaan-kebiasaan masyarakat termasuk penguasaan bahasa setempat. Hal ini menjadi penting karena penguasaan bahasa setempat adalah salah satu yang utama, jika tidak dapat disebut satu-satunya, untuk mempelajari dan menguasai pemahaman tentang suatu wilayah yang ditelitinya (Winichakul, 2016). Pada titik ini, diversifikasi topik dan sumber-sumber sejarah dalam penelitian sejarah lokal sangat memungkinkan untuk dilakukan. Meskipun arsip masih mengambil peranan penting di dalam penulisan sejarah, penggunaan sumber-sumber alternatif seperti folklor, cerita rakyat, dongeng, mitos dan tradisi/sejarah lisan lainnya memungkinkan untuk menyusun sejarah yang holistik.

Perkembangan ini tentunya mengarah pada koreksi dari keterbatasan definisi sejarah lokal seperti yang disampaikan oleh Taufik Abdullah (1996), melihat sejarah lokal secara struktural terbatas pada lokalitas tertentu yang memiliki kekurangan catatan (dokumen) tentang perkembangan suatu daerah di periode tertentu. A B Lapian misalnya, dalam menyusun disertasi yang kemudian diterbitkan dengan judul "Orang Laut, Bajak Laut, dan Raja Laut: Sejarah Kawasan Laut Sulawesi Abad XIX' memperlihatkan bahwa sejarah lokal (kawasan laut Sulawesi) merupakan interaksi yang dinamis 
dari orang-orang yang berada di wilayah tersebut dengan lingkungan sekitarnya, dan dengan kekuatan sejarah (sosial-politik) dari luar melalui aktivitas perdagangan (laut) yang menciptakan kondisi ekologi kemaritiman yang berbeda dengan ekologi agraris (Lapian, 2009). Usaha yang dirintis oleh A B Lapian ini kemudian disebut sebagai sejarah maritim (sejarawan maritim) meskipun dikembangkan berdasarkan rintisan sejarah sosial ala Sartono. Bagi A.B. Lapian sejarah sosial (orang kecil) itu tidak hanya terjadi di arenan daratan namun juga terjadi di arena laut.

Dalam konteks yang lebih luas, sejarah maritim Indonesia ini merupakan bagian dari sejarah kawasan Asia Tenggara. Anthony Reid mengatakan bahwa upaya penyusunan sejarah Asia Tenggara sama halnya dengan upaya penyusunan sejarah total. Reid menyebutkan bahwa sejarah Asia Tenggara telah membuktikan bahwa wilayah ini merupakan satu entitas besar yang tidak pernah terpisahkan secara geografis maupun sosial kulturalnya. Konstelasi wilayah ini telah menciptakan sebuah pertalian budaya dalam rentang waktu yang panjang dan mencapai puncaknya pada masa yang disebut oleh Reid sebagai zaman niaga (Hall, 1955, Reid, 2011). Muridnya Adrian Vickers, kemudian menjelaskan proses penciptaan itu sebagai bentuk dari sebuah peradaban bersama Asia Tenggara yang disebut sebagai peradaban pesisir (Vickers, 2009). Lain lagi dengan Dennys Lombard yang menyebut kawasan ini (Jawa) sebagai arena pertautan kebudayaan yang membentuk lapisan-lapisan peradaban yang diterima, diolah dan dikembangkan dari kebudayaan India, Islam, dan Eropa (Lombard, 2005).

Penulisan sejarah maritim di tingkat lokal kemudian terus berkembang dengan berbagai topik dan penggunaan sumber sejarah yang lebih beragam meskipun masih sangat tergantung kepada sumber- sumber arsip kolonial. Topik- topik sejarah maritim ini kemudian berkembang berdasarkan aspek yang saling terkait satu sama lain seperti, integrasi wilayah (hinterland dan foreland) seperti yang dilakukan oleh $\mathrm{F}$. A Sutjipto Tjiptoatmojo (1983) tentang kota-kota di Selat Madura, Susanto Zuhdi (2015) melihat perkembangan Pelabuhan Cilacap dan Edward Poelinggomang (2002) tentang Makassar, aspek etnisitas oleh Andi Ima Kesuma (2004) pola migrasi Orang Bugis dan Abd. Rahman Hamid (2011) tentang orang Buton, dan aspek komoditas seperti yang dilakukan oleh Imam Syafi'i (2013) mengenai perdagangan garam, dan aspek sosial-politik yang ditulis oleh Rasyid Asba (2007) tentang kopra Makassar. Tentunya lebih banyak lagi penelitian-penelitian sejarah maritim di tingkat lokal yang memberikan kesempatan kepada kita tentang berbagai aspek-aspek lain dari sejarah maritim di tingkat lokal, sekalipun dari aspek-aspek tersebut tetap saling berkaitan, seperti permasalahan buruh, perempuan, anak, nelayan, kuliner (Bustami, 2004), sejarah lingkungan (Lapian, 1999) dan lain sebagainya.

Hal terakhir yang perlu disampaikan adalah terkait dengan penyelenggaraan Konferensi Nasional Sejarah (KNS) ke-10 yang diselenggarakan di Jakarta pada tahun 2016 di Jakarta (7-10 November). Konferensi yang mengangkat tema sejarah maritim ini memiliki signifikansi yang penting terhadap perkembangan penulisan sejarah maritim di tingkat lokal. Dari sekian banyak makalah yang masuk dan dipresentasikan prospek penulisan sejarah maritim di tingkat lokal memperlihatkan bahwa lokalitas tidak hanya diartikan sebagai unit analisis geografis tertentu, lebih dari itu lokalitas harus dilihat dari sejauh mana wilayah tertentu itu memiliki keterkaitan dan konektivitas dengan wilayah lain baik 
secara kultural, ekonomi, politik dan budaya. Makalah-makalah yang masuk dan dipresentasikan ini tidak hanya menawarkan suatu wilayah yang relatif baru dengan sumber-sumber yang belum dipublikasikan sebelumnya di dalam kajian sejarah maritim, juga keberagaman topik yang dimunculkan. Yang perlu mendapatkan perhatian terkait kegiatan konferensi ini adalah, kajian Sulawesi mendapatkan tempat yang paling banyak dipresentasikan oleh sarjana-sarjana lokal yang memang berasal dari pulau ini. Berikutnya, makalah-makalah yang membahas tentang sejarah maritim di bagian timur Indonesia, selain Sulawesi tentunya, juga relatif minim. Namun yang menarik adalah makalah yang dipresentasikan oleh Tika Ramadani (2016) dari Universitas Leiden yang mengkaji diaspora orang Arab di Kepulauan Sunda Kecil. Tulisan ini kemudian menjelaskan sejauh mana dinamika perdagangan kuda yang dilakukan orangorang Arab di Kepulauan Sunda Kecil sesungguhnya terkoneksi dengan orangorang Arab di kota-kota besar seperti Surabaya dan Jakarta. Bagaimanapun, sejarah maritim di tingkat lokal telah menunjukkan kepada kita bahwa hampir semua wilayah di Indonesia memiliki konektivitas satu sama lain, menciptakan mobilitas, komunikasi, diaspora berbagai etnis yang membentuk peradaban bersama yang kosmopolit.

\section{SEJARAH LOKAL DAN TAN- TANGAN KEKINIAN: CATATAN PENUTUP}

Keberagaman narasi yang muncul dari upaya penulisan sejarah lokal yakni semakin banyaknya periodisasi, peristiwa dan pelaku sejarah yang mampu mengungkapkan lapisan-lapisan peradaban masyarakat yang terbentuk dari pengalaman dan sejarah kolektif kita. Bahwa tradisi historiografi yang bertumpu pada perkembangan masyarakat kita sebagai sebuah nation-state, dapat merelasikan dengan baik antara historiografi nasional dan historiografi lokal tanpa terjebak pada perdebatan dikotomis dan konfrontatif di antara keduanya. Bahwa sejarah nasional dan sejarah lokal tidak harus selalu memiliki dimensi yang sama atau harus berbeda sama sekali baik dari aspek spasial, temporal serta pelaku- pelaku sejarah baik secara individual dan atau kelompok.

Masing-masing masyarakat tentu saja memiliki ingatan-ingatan masa lalu baik individu maupun ingatan kolektif. Ingatan-ingatan ini tentu saja memiliki berbagai macam bentuk sesuai dengan eksistensi masyarakat itu sendiri yang tetap dipertahankan sebagai sebuah tradisi. Pemahaman yang memadai akan pentingnya eksistensi sebuah tradisi ini kemudian akan mempermudah kerja kita untuk merekonstruksi setiap narasi masa lalu dari masingmasing suku bangsa. Menyeimbangkan kerja-kerja tendensius dan menghindari stereotipe seperti yang dilakukan di dalam tradisi historiografi konvensional yang hanya bertumpu pada sumber arsip yang dianggap memiliki kemutlakan validitas informasi.

Pada akhirnya, setiap generasi selalu berupaya memiliki dan menulis sejarahnya sendiri. Namun, upaya itu tidak tumbuh di ruang hampa melainkan dipengaruhi oleh situasi sosial-politik yang terus berkembang. Oleh karenanya, arah historiografi hari ini harus mampu menjawab berbagai permasalahan kita sebagai nation-state terutama munculnya kembali premordial, sektarianisme, dan eksklusifisme kelompok-kelompok tertentu. Upaya penulisan sejarah maritim di aras lokal harus dilihat sebagai bagian dari tradisi historiografi lokal yang memberikan peluang terhadap keberagaman narasi dan meyakinkan kita bahwa perbedaan adalah 
keniscayaan yang perlu diperjuangkan secara kolektif melalui prinsip multikulturalisme. Secara bersamaan, sejarah maritim lokal juga harus memberikan kita batasan sejauh mana multikulturalisme itu dikembangkan karena pengalaman kemaritiman kita yang panjang memberikan kita ikatan yang kosmopolit, masyarakat yang luwes dan terbuka. Artinya, pada level ini, sejarah maritim lokal memberikan makna bahwa multikulturalisme merupakan identitas dan pengalaman sejarah kolektif kita sebagai bangsa dan harus menjadi prinsip- prinsip kewarganegaraan yang sejajar dalam negara-bangsa atau apa yang disebut sebagai komunitas terbayang. Harapannya, usaha ini akan membawa kita kepada pemahaman dan kearifan yang lebih besar tentang masa lalu kita sebagai sebuah bangsa. Sebuah pemahaman dan kearifan sebagaimana terkandung dalam sebuah pameo lama "In het heden light het verleden, in het $n u$ wat komen zal" yang kurang lebih memiliki arti "di masa kini terletak masa lalu, di masa sekarang terkandung masa depan".

\section{DAFTAR RUJUKAN}

Abdullah, T. (ed). 1996. Sejarah Lokal di Indonesia: Kumpulan Tulisan.Yogyakarta: Gajah Mada Uniersity Press.

2016. "Historiografi dalam Denyut Sejarah Bangsa" Makalah disampaikan di dalam ceramah tentang Historiografi Indonesia dalam Perspektif Sejarah di Teater Salihara.

Abdullah, T. dan Surjomihardjo, A. (Ed) 1985. Ilmu Sejarah dan Historiografi: Arah dan Perspektif. Jakarta: Gramedia.
Adam, A.W. 2000. "Sejarah Lisan di Asia Tenggara, Sejarah Korban di Indonesia" pengantar dalam P. Lim Pui Huen, dkk, Sejarah Lisan di Asia Tenggara: Teori dan Metode terjemahan oleh $\mathrm{R}$ Z Leirissa. Jakarta: LP3ES. 2006. "Pengantar: Berfikir Historis Membenahi Sejarah" dalam Sam Wineburg, Berfikir Historis: Memetakan Masa Depan, Mengajarkan Masa Lalu terjemahan Masri Maris. Jakarta: Yayasan Obor Indonesia.

2010. Bung Karno Dibunuh Tiga Kali?: Tragedi Bapak Bangsa Tragedi Indonesia. Jakarta: Penerbit Buku Kompas.

Asba, R. 2007. Kopra Makassar, Perebutan Pusat dan Daerah: Kajian Sejarah Ekonomi Politik Regional Indonesia. Jakarta: Yayasan Obor Indonesia.

Bustami, A. L., 2009. "Folklor Kangean: Suatu Kajian Cerita Bajak Laut (lanun) Sebagai Sumber Sejarah Kawasan" Jurnal Bahasa dan Seni, Tahun 32, Nomor 2, Agustus 2004. Sumber: http://sastra.um.ac.id/wp-content/uploads/2009/10/Foklor-

Kangean- Suatu-KajianCerita-Bajak-Laut-SebagaiSumber-Sejarah- Kawasan.pdf diakses pada 17 April 2017.

Departemen Pendidikan Nasional. 2001 Kumpulan Makalah Diskusi 
Sejarah Lokal: Konflik Komunal dan Keterasingan Sosial. Jakarta: Suko Rejo Bersinar. .2001. Kumpulan Makalah Diskusi Sejarah Lokal: Pembangkangan Sipil dan Konflik Vertikal. Jakarta: Suko Rejo Bersinar.

De Graaf, H.J. 1971. Historiografi Hindia Belanda terjemahan $\mathrm{CPF}$ Luhulima. Jakarta: KITLV dan LIPI.

Hamid, A. R. 2011. Orang Buton: Suku Bangsa Bahari Indonesia.Yogyakarta: Ombak.

Hasan, Husaini M. 2016. Dari Gunung Halimon ke Swedia: Catatan Pelaku Sejarah Dr. Husaini M Hasan Ketika Bersama Tengku Hasan M di Tiro. Jakarta: Yayasan Kerukunan Aceh Antar Bangsa.

Kartodirdjo, Sartono. 1995. Perkembangan Penulisan Sejarah di Indonesia Selama Setengah Abad: Teori dan Praktek (Makalah disampaikan pada Seminar Nasional Setengah Abad Budaya Indonesia pada Fakultas Sastra Universitas Diponegoro Semarang. - 1982. Pemikiran dan Perkembangan Historiografi Indonesia: Suatu Alternatif. Jakarta: Gramedia.

Kesuma, A.I, Migrasi dan Orang Bugis: Penelusuran Kehadiran Opu Daeng Rilakka Pada Abad XVIII di Johor (Yogyakarta: Ombak, 2004).

Lane, M. R., 2011. "Suatu Sejarah Alternatif Indonesia" dalam Malcolm Caldwell dan Ernst Utrecht, Sejarah Alternatif Indonesia terjemahan Saut Pasaribu. Bogor: Djaman Baroe dan Sajogyo Institute.

Lapian, A B., 1999. "Nusantara: Silang Bahari" dalam Henri Chambert Loir (Ed),
Panggung Sejarah:

Persembahan Kepada Prof.

Dr. Denys Lombard. Jakarta:

Yayasan Obor Indonesia. . 2009. Orang Laut, Bajak Laut, Raja Laut: Sejarah Kawasan Laut Sulawesi Abad XIX. Jakarta: Komunitas Bambu.

Leirissa, R.Z., 1973. "Kata Pengantar Buku J. C van Leur, Abad Ke-18 Sebagai Kategori Dalam Penulisan Sejarah Indonesia. Jakarta: Bhratara.

Maat, H., 2016. "Upland and Lowland in Netherlands Indies" dalam Sandip Hazareesingh dan Harro Maat (ed), Local Subversions of Colonial Cultures: Commodities and Anti-Commodities in Global History. Cambridge Imperial and PostColonial Studies Series: Palgrave Macmillan.

Morrison, J. H., 2000. "Perspektif Global Sejarah Lisan di Asia Tenggara", dalam P. Lim Pui Huen, dkk, Sejarah Lisan di Asia Tenggara: Teori dan Metode terjemahan oleh R Z Leirissa. Jakarta: LP3ES.

Nordholt, H.S (ed). 2008. Perspektif Baru Penulisan Sejarah Indonesia. Jakarta: Yayasan Obor Indonesia dan KITLV.

Nursam, M. 2008. Membuka Pintu Bagi Masa Depan: Biografi Sartono Kartodirdjo. Jakarta: Gramedia.

Poelinggomang, E. 2002. Makassar Abad XIX: Studi tentang Kebijakan Perdagangan Maritim. Jakarta: KPG.

Purwanto, B. 2006. Gagalnya Historiografi Indonesiasentris. Yogyakarta: Ombak.

Ramadani, T., 2016. "Mencari Cincin Nabi Sulaiman di Timur Hindia Belanda: Migrasi Arab di Kepulauan Sunda Kecil, Abad ke-19 dan 20" Makalah disampaikan dalam 
Konferensi Nasional Sejarah $X$ di Jakarta pada 7-10 November.

Reid, A. 2011. Asia Tenggara dala Kurun Niaga, 1450-1680: Jaringan Perdagangan Global. Jakarta: Yayasan Obor Indonesia. 2011. Asia Tenggara dala Kurun Niaga, 1450-1680: Tanah di Bawah Angin. Jakarta: Yayasan Obor Indonesia.

Soedjatmoko dkk., 1995. Historiografi Indonesia terjemahan Mien Djubhar. Jakarta: Gramedia.

Syafi'i, I., 2013. "Dari Selat Menuju Samudra Luas: Rivalitas Pengangkutan Garam Madura 1912-1980". Tesis Magister Sejarah Universitas Diponegoro.

Tirtosudarmo, R. 2007. Mencari Indonesia: Demografi Politik Pasca Soeharto. Jakarta: LIPI Press dan Yayasan Obor Indonesia.

Tjiptoatmojo, F. A Sutjipto., 1983. "Kota-kota Pantai di Sekitar Selat Madura Abad XIX sampai Medio Abad XIX". Disertasi Doktoral Ilmu Sejarah pada Fakultas Sastra Universitas Gadjah Mada.

Toer, Pramoedya Ananta., 1999.

"Best Story: The Book That Killed Colonialism" sumber: http://www.nytimes.com/1999/04/18/magazine/best-story-the-book- thatkilled-colonialism.html diakses pada Rabu, 5 April 2017.

Van Leur, J. C . 1973. Abad ke- 18 Sebagai Kategori Dalam Penulisan Sejarah Indonesia terjemahan Koentjaraningrat, dkk. Jakarta: KITLV dan LIPI.

Vickers, A. 2009. Peradaban Pesisir: Menuju Sejarah Budaya Asia terjemahan Arif
B Prasetyo. Bali: Pustaka Larasan.

Winichakul, T, 2016. "Area /Asian Studies: Past, Present, and Prospect" Makalah disampaikan dalam public lecture yang diselenggarakan oleh P2SDR LIPI pada 20-21 Oktober 2016 di LIPI Jakarta.

Zed, M., 2012. "Arti Konflik Papua dalam Konstruksi Sejarah Indonesia" dalam Ardimanto, dkk (ed), Oase Gagasan Papua Damai. Jakarta: Imparsial.

Zuhdi, Susanto. 2015. Cilacap 18301942: Bangkit dan Runtuhnya Suatu Pelabuhan di Jawa. Yogyakarta: Ombak. 